\title{
Gaya Komunikasi dan Kepemimpinan Kapolres Indarto dalam Meningkatkan Kinerja Polres Metro Bekasi Kota
}

\section{Communication Style and Leadership of Indarto Kapolres in Improving The Performance of The Metro Bekasi City}

\author{
Marlina*, Lona Kurniaty \& Shendy Tamica \\ LSPR Communication \& Business Institute, Indonesia
}

Diterima: 08 April 2020; Disetujui: 01 Mei 2020; Dipublish: 01 Juli 2020

\begin{abstract}
Abstrak
Gaya komunikasi dan kepemimpinan seseorang pemimpin merupakan sebuah kunci untuk meningkatkan kualitas kinerja para anggotanya untuk mencapai target kesuksesan. Begitu pula dengan Kepala Kepolisian Resor Indarto, yang berhasil memimpin para anggota kepolisiannya hingga Kepolisian Resor Metro Bekasi Kota berhasil menerima berbagai penghargaan atas prestasiprestasinya. Karena itulah Tujuan dari penelitian ini adalah untuk memahami bagaimana gaya komunikasi dan gaya kepemimpinanIndarto selaku Kapolres dalam meningkatkan kinerja para anggota Polres Metro Bekasi Kota, dan hal-hal apa saja yang mempengaruhi pelaksanaan gaya komunikasi Indarto sebagai pimpinan. Penelitian ini menggunakan pendekatan kualitaitif, dengan tehnik pengumpulan data melalui wawancara, observasi, dan literature review. informan dalam penelitian ini dipilih dengan Teknik Purposive Sampling. Data-data yang terkumpul dianalisi dengan menggunakan Teknik triangulasi data. Hasil penelitian ini menunjukkan bahwa gaya kepemimpinan yang digunakan oleh Kapolres Indarto adalahAutocratic styledan Democratic Style. Sedangkan untuk gaya komunikasi Kapolres Indarto adalah Controlling style, Dynamic style, dan Reliquishing style.

Kata Kunci: Gaya kepemimpinan, Gaya komunikasi, Polres Metro Bekasi Kota
\end{abstract}

\begin{abstract}
Communication style and leadership of a leader is a key to improving the quality of the performance of its members to achieve success targets. Likewise with the Chief of the Indarto Resort Police, who managed to lead members of his police force until the Bekasi City Metro District Police succeeded in receiving various awards for his achievements. That's why the purpose of this research is to understand how Indarto's communication style and leadership style as the Police Chief in improving the performance of members of the Jakarta Bekasi City Police Precinct, and what things influence the implementation of Indarto's communication style as a leader. This research uses a qualitative approach, with data collection techniques through interviews, observation, and literature review. the informants in this study were selected by using purposive sampling technique. The data collected is analyzed using data triangulation techniques. The results of this study indicate that the leadership style used by the Indarto Police Chief is the Acocratic style and Democratic Style. Whereas the communication style for Indarto Police Chief is the Controlling style, Dynamic style, and Reliquishing style
\end{abstract}

Keywords: Leadership style, Communication style, Bekasi City Metro Police

How to Cite: Marlina, Kurniaty, L. Tamica, S. (2020). Gaya Komunikasi Dan Kepemimpinan Kapolres Indarto Dalam Meningkatkan Kinerja Polres Metro Bekasi Kota. PERSPEKTIF, 9(2): 346-353 


\section{PENDAHULUAN}

Sebagai mahluk sosial, manusia tentu membutuhkan dan diharuskan untuk berkomunikasi di kehidupan sehari-harinya. Sebagian besar waktu manusia digunakan untuk berkomunikasi, baik komunikasi verbal maupun non verbal. Pesan yang disampaikan dalam komunikasi memiliki makna masingmasing. Gesture tubuh dan intonasi suara juga memiliki peranan dalam komunikasi.Pesan verbalatau non verbal dari komunikator kepada komunikan tentu memiliki tujuan yang ingin dicapai. Menyatakan belas kasihan, motivasi, kemarahan, menyampaikan perintah dan sebagainya adalah contoh beragam tujuan dari komunikasi. Gaya komunikasi merupakan perilaku pribadi yang khas dalam situasi dan kondisi tertentu.Berbicara mengenai komunikasi, setiap orang tentu memiliki gaya komunikasi yang berbeda-beda.

Terutama bagi seorang pemimpin. Seorang pemimpin memiliki tanggung jawab untuk dapat mengarahkan dan menuntun para anggotanya untuk dapat bekerja dengan baik sesuai dengan target tujuannya.Penting bagi seorang pemimpin untuk menetukan gaya komunikasi yang tepat sesuai dengan karakteristik anggotanya dan memutuskan gaya komunikasi seperti apa yang harus dilakukannya dalam situasi dan kondisi tertentu. Gaya komunikasi seorang pemimpin akan menjadi kunci keberhasilan membawa para anggotanya untuk dapat bekerja dengan baik dan mencapai tujuan yang diharapkannya. Selain itu, gaya kepemimpinan seseorang juga merupakan hal yang sangat berpengaruh karena dapat menentukan keberhasilan pemimpin itu sendiri.

Karena itulah gaya Komunikasi dalam kepemimpinan merupakan salah satu hal yang menarik untuk dibahas terkait dengan pentingnya gaya komunikasi seseorang. Komunikasi dalam kepemimpinan yang baik akan memastikan tiap anggota organisasinya dapat mengerjakan tugas-tugasnya dengan baik. Gaya komunikasi kepemimpinan harus digunakan oleh Pemimpin untuk mempengaruhi anggota atau bawahannya dalam mencapai target tujuan organisasi. Begitupun dalam organisasi Kepolisian.Organisasi Kepolisian merupakan merupakan Lembaga hukum yang juga menjadi bagian dari aparatur pemerintah. Polisi bekerja tanpa sekat untuk melayani masyarakat. Di era sekarang ini, tantangan bagi kepolisian semakin berat. Masyarakat menuntut ingin dilayani dengan baik oleh Kepolisian tanpa adanya birokrasi yang merepotkan apalagi menyusahkan. Kepolisian juga harus menjaga dan memastikan keamanan dan ketertiban masyarakat. Pemimpin dalam organisasi kepolisian sangat berperan dalam mencapai tujuan Lembaga kepolisian.

Salah satunya adalah Kepolisian Resor Metro Bekasi Kota, yang merupakan lembaga kepolisian yang memiliki wewenang dan tanggung jawab dalam melayani masyarakat kota Bekasi dengan baik dan menjaga keamanan dan ketertiban Kota Bekasi. Namun, saat ini Kepolisian Resor Metro Bekasi Kotatengah menjadi sorotan publik dengan berbagai pencapaian prestasinya diantaranyaPada tanggal 28 september 2018, polres Metro Bekasi Kota berhasil mendapatkan 2 penghargaan sekaligus, yang pertama adalah juara 1 tingkat Lomba Kawasan Tertib Lalu Lintas (KTL) tingkat nasional dimana penghargaan ini diserahkan langsung oleh kepala Korps Lalu Lintas RI di markas Kakorlantas. Penghargaan kedua adalah Polres Metro Bekasi Kota berhasil mempertahankan juara satu dalam lomba Road Safety Partnership Action (RSPA) tingkat polda, dan penghargaan ini adalah yang ketiga kalinya. (website resmi Polres Metro Bekasi Kota).

Tidak hanya itu Polres Metro Bekasi Kota juga meraih dua penghargaan dari Museum Rekor Dunia Indonesia (MURI) saat memperingati hari Bhayangkara ke-73 tingkat kota Bekasi. Penghargaan rekor pertama sebagai penyelenggara pelayanan pelayanan Surat Izin Mengemudi (SIM) dan (Surat Keterangan Catatan Kejahatan (SKCK) 24 jam secara berkelanjutan terlama sejak 11 Juli 2018 dan masih berlangsung hingga sekarang, sementara rekor ke dua diberikan kepada keanggotaan Polsubsektor Pekayon dan Posubsektor Mekar Sari yang seluruhnya merupakan Polwan. (Firdaus, 2019, ayobekasinet, para. 1). Bahkan saat iniPolres metro Bekasi Kota mendapatkan pengakuan WBK (Wilayah Bebas Korupsi) dan mendeklarasikan WBBM (Wilayah Birokrasi Bersih dan Melayani).

Berbagai prestasidan reformasi birokrasi yang dicapai oleh Kepolisian Resor Metro 
Bekasi Kota, tentu tidak terlepas dari kepemimpinan Komisaris Besar Polisi Dr. Indarto, S.H., S.Sos., S.I.K., M.Si. sebagai Kepala Polisi Resor yang mengemban amanah sebagai Kapolres Metro Bekasi Kota sejak 16 November 2017. Indarto juga meraih Berhasil menjadi juara 1 dalam pemilihan Polisi Teladan Sebagai Penggerak Revolusi Mental dan Pelopor Tertib Sosial di Ruang Publik T.A 2019 serta Penghargaan juga diberikan karena Kapolres Indarto dinilai telah menciptakan wilayah bebas korupsi di kota Bekasi. (Wildansyah, 2019, para. 1). Keberhasilan dan prestasi Kepolisian Resor Bekasi Kota tentu juga karena kinerja yang luar biasa dari para anggota kepolisiannya. Untuk mencapai kualitas kinerja yang diharapkan dalam tubuh Polres Metro Bekasi Kota, gaya kepemimpinan dan gaya komunikasi yang tepat dari Indarto tentu merupakan hal yang esensial dan sangat berpengaruh.

Indarto harus mampu untuk menentukan gaya komunikasi dan kepemimpinan seperti apa yang cocok di implementasikan didalam organisasinya. Gaya komunikasi dan kepemimpinan yang tepat tentu akan menjadi kunci keberhasilan dalam menciptakan kualitas yang baik bagi kinerja para anggota kepolisiannya dalam lingkup Polres Metro Bekasi Kota. Sebagai seorang pemimpin, Indarto tidak akan dapat menjalan kan visi dan misi polresto Bekasi Kota jika tidak dibarengi dengan gaya komunikasi dan gaya kepemimpinan yang sesuai. Sebagai mana visi Polres Metro Bekasi kota adalah terwujudnya pelayanan Kamtibmas yang unggul, terjalinnya kemitraan Polrestro Bekasi Kota dengan masyarakat, penegakkan hukum yang efektif serta sinergi polisional yang proaktif dalam memantapkan keamanan di wilayah hukum PolrestroBekasi Kota. Sedangkan misinya adalah:

1. meningkatkan pelayanan Kamtibmas prima melalui kegiatan preemtif, preventif dan represif (penegakkan hukum) dengan menerapkan ilmu pengetahuan dan teknologi guna mewujudkan keamanan di wilayah hukum Polrestro Bekasi Kota yang kondusif;

2. memperkuat dan meningkatkan peran intelijen keamanan dalam melaksanakan deteksi dini dan deteksi aksi secara cepat dan akurat melalui kegiatan penyelidikan, pengamanan dan penggalangan;
3. mewujudkan penegakkan hukum secara profesional dan proporsional yang tidak diskriminatif, menjunjung tinggi HAM, anti KKN dan anti kekerasan;

4. memberdayakan peran Bhabinkamtibmas dalam mengimplementasikan strategi Polmas pada setiap desa/kelurahan dan komunitas masyarakat lainnya;

5. mengembangkan sistem sinergi polisional dengan instansi terkait maupun komponen masyarakat dalam rangka membangun kemitraan; dan

6. mewujudkan keamanan, keselamatan, ketertiban dan kelancaran lalu lintas untuk menjamin keselamatan dan kelancaran arus orang dan barang, peraturan perusahaan, dan meningkatkan kinerja karyawan dengan baik tanpa adanya kerjasama dari seluruh pihak yang terdapat di dalam perusahaan tersebut.

Tidak hanya visi dan misi yang harus dijalankan, namun juga ada Sasaran Prioritas Polrestro Bekasi Kota yang juga harus diutamakan. Seperti:

1. mewujudkan profesionalisme SDM Polrestro Bekasi Kota yang unggul melalui pendidikan dan latihan di bidang Harkamtibmas, Gakkum dan pelayanan masyarakat;

2. mewujudkan sistem pembinaan personel melalui rekrutmen Polri dan PNS Polrestro Bekasi Kota, pendidikan pembentukan, pendidikan pengembangan dan pelatihan serta pembinaan karier yang bebas dari Korupsi, Kolusi dan Nepotisme (KKN), transparan, akuntabel dan humanis guna membangun internal trust dan public trust;

3. mewujudkan penguatan integritas seluruh personel Polrestro Bekasi Kota dalam menjalankan Tupoksi secara transparan dan akuntabel melalui pembangunan zona integritas menuju Wilayah Bebas dari Korupsi (WBK) dan Wilayah Birokrasi Bersih dan Melayani (WBBM) terutama pada sector pelayanan publik, penegakan hukum, pengelolaan anggaran, pengadaan barang dan jasa yang didukung dengan pengawasan yang efektif dalam rangka mencegah praktek Korupsi, Kolusi dan Nepotisme (KKN);

4. meningkatkan aksesibilitas pelayanan Polri kepada masyarakat di wilayah hukum Polrestro Bekasi Kota dengan penguatan 
bidang kehumasan sebagai implementasi keterbukaan informasi publik guna mewujudkan kepercayaan masyarakat (Public Trust);

5. meningkatkan pengawasan secara efektif untuk mewujudkan pelayanan Polri yang bebas dari Korupsi, Kolusi dan Nepotisme (KKN);

6. terpenuhinya teknologi Kepolisian dan dukungan teknis Kepolisian (seperti peralatan Labfor, Identifikasi, cyber lab dan DVI);

7. melanjutkan pembangunan gedung baru Polrestro Bekasi Kota guna menciptakan ruang kerja yang lebih representativ dalam rangka meningkatkan pelayanan kepada masyarakat;

8. meningkatkan Kerma lintas Kementerian/Lembaga, criminal justice system (Kejaksaan, Pengadilan, Lapas) serta komponen masyarakat dalam menciptakan situasi Kamtibmas yang kondusif dan penanganan konflik sosial;

9. penguatan fungsi Kepolisian dalam rangka Harkamtibmas dengan meningkatkan early detection (deteksi dini) dan early warning (peringatan dini) untuk menjangkau seluruh sendi kehidupan masyarakat dengan mengedepankan 1 (satu) Bhabinkamtibmas 1 (satu) desa;

10. pengungkapan kasus-kasus menonjol yang meresahkan masyarakat yang meliputi kejahatan konvensional, kejahatan lintas negara/transnational crime, kejahatan yang merugikan kekayaan negara dan kejahatan yang berimplikasi kontinjensi;

11. terselenggaranya imbangan informasi positif kepada masyarakat dalam rangka menjaga stabilitas Kamtibmas melalui kinerja positif Polrestro Bekasi Kota; dan

12. mewujudkan Kamseltibcarlantas melalui penurunan jumlah titik-titik rawan kecelakaan lalu lintas untuk mengurangi jumlah dan tingkat fatalitas kecelakaan serta menguraikan kemacetan dan kelancaran lalu lintas di wilayah hukum Polrestro Bekasi Kota.

Hal ini tentu akan menjadi pekerjaan rumah untuk para anggota polisi resor, terutama Indarto selaku Kepala Kepolisian Resor Bekasi Kota. Itulah mengapa gaya kepemimpinan dan komunikasi yang tepat sangat di butuhkan untuk dapat menjalankan visi dan misi serta merealisasikan sasaran prioritas utama tersebut diatas agar dapat melayani kepentingan masyarakat banyak dengan baik. Karena hal inilah Penulis tertarik untuk meneliti jenis Gaya komunikasi dan kepemimpinan seperti apa yang digunakan dan diimplemetasikan oleh Indarto sebagai Kapolres sehingga Polres Metro Bekasi Kota dapat mencapai prestasi-prestasinya.

\section{METODE PENELITIAN}

Design penelitian yang digunakan dalam penelitian ini adalah kualitatif. Sebagaimana yang didefinisikan oleh Bogdan dan Taylor (1975) bahwa metodologi kualitatif merupakan prosedur penelitian yang menghasilkan data deskriptif berupa kata kata tertulis atau lisan dari orang-orang dan perilaku yang dapat diamati. (Moleong, 2017).

Terdapat dua jenis sumber data dalam penelitian ini, yaitu data primer dan data sekunder. data primer merupakan data yang didapat dari sumber pertama baik dari individu maupun perseorangan seperti hasil dari wawancara atau hasil pengisian kuisioner yang biasa dilakukan oleh peneliti. Data Sekunder merupakan data primer yang telah diolah lebih lanjut dan disajikan baik oleh pihak pengumpuldata primer atau oleh pihak lain misalnya dalam bentuk tabel-tabel atau diagram-diagram(Umar, 2011).

Data primer dalam penelitian ini berupa hasil wawancara mendalam peneliti dengan Indarto selaku Kapolres metro Bekasi Kota, beserta beberapa anggota Polres Metro Bekasi Kota seperti anggota divisi satuan lalu lintas, anggota panit 1 unit 2 Narkoba Polres Metro Bekasi kota, Kepala satuan Reskrim Polres Metro Bekasi Kota, kepala bagian Ren Polres Metro Bekasi Kota, serta sekretaris dan ajudan pribadiIndarto. Sedangkan sumber data sekunder dalam penelitian ini didapat dari literature review, buku-buku teori dan metodologi, website resmi Polres Metro Bekasi Kota, dan beberapa laman portal berita yang menyoroti prestasi-prestasi Polres Metro Bekasi Kota.

Dalam penelitian kualitaitif, Teknik sampling yang paling banyak digunakan adalah Puposive sampling. Purposive Sampling adalah teknik pengambilan sampel sumber data dengan pertimbangan tertentu. Pertimbangan tertentu ini, misalnya orang tersebut yang dianggap paling tahu tentang apa yang kita harapkan atau mungkin dia 
sebagai penguasa sehingga akan memudahkan peneliti menjelajahi objek/situasi sosial yang di teliti (Moleong, 2017, p. 289). Karena fokus penelitian ini untuk memahami gaya kepemimpinan dan gaya komunikasi yang di lakukan oleh Indarto dalam organisasi nya, maka yang menjadi sampel sebagai sumber data penelitian ini adalah Indarto dan beberapa staff khusus nya di badan kepolisian.

Teknik pengumpulan data yangdigunakan untuk membantu penulisdan mempermudah dalam menyusunpenelitian ini adalah denganmeggunakan teknik pengambilandata melalui wawancara dengan narasumber yang terkait dengan penelitian ini, observasi langsung ke kantor Polres Metro Bekasi Kota,dan dokumentasi.

Analisis data kualitatif menurut Bogdan \& Biklen (1982) adalah upaya yang dilakukan dengan jalan bekerja dengan data, mengorganisasikan data, memilah-milahnya menjadi satuan yang dapat dikelola, mensistesiskannya, mencari dan menemukan pola, menemukan apa yang penting dan apa yang dipelajari, dan memutuskan apa yang dapat diceritakan kepada orang lain (Moleong, 2017 , p. 248). Dalam penelitian ini, data yang didapat dari hasil wawancara di olah dengan menggunakan metode kualitatif dan dan diuraikan dengan teori-teori dan konsepkonsep yang relevan dengan pembahasan yang dilakukan dalam penelitian ini, yaitu gaya komunikasi dan gaya kepemimpinan.

Teknik pemeriksaan keabsahan data pada penelitian ini menggunakan Teknik triangulasi. Triangulasi adalah teknik pemeriksaan keabsahan data yang memanfaatkan sesuatu yang lain.Di luar data itu untuk keperluan pengecekan atau sebagai pembanding terhadap keperluan data itu. Teknik Triangulasi sebagai Teknik pemeriksaan yang memanfaatkan penggunaan sumber, metode, penyidik, dan teori (Moleong, 2017, p. 330).

\section{HASIL DAN PEMBAHASAN}

\section{Gaya Kepemimpinan Indartos ebagai Pimpinan dalam Meningkatkan Kinerja Polres Metro Bekasi Kota}

Gaya kepemimpinan berpengaruh kepada kinerja organisasi secara keseluruhan. Keberhasilan sebuah organisasi tergantung bagaimana seorang pemimpin dapat mengatur berbagai elemen didalam organisasinya demi mencapai tujuan yang dikehendaki. Saat menjabat Kapolres metro Bekasi bulan November 2017, Kapolres Metro Bekasi Kota menghadapi kenyataan bahwa di lingkungan Polres, terjadi budaya koruptif, tidak berintegritas, pelayanan buruk dan lain-lain. Sehingga untuk melakukan perubahan 180 derajat yang extreme, berdasarkan situasi yang ada, Indarto menggunakan gaya kepemimpinanAutocratic Style, berupa komunikasi top-down.

Indarto mengajak seluruh anggotanya untuk mendeklarasikan zona integritas dengan menolak pungutan liar, menolak korupsi serta kegiatan lain yang bersifat gratifikasi pada saat bekerja dan melayani masyarakat. Dalam melakukan doktrin integritas ini, diperlukan pola otoritor. Bahkan, pada saat itu Indarto mempersilahkan anggotanya yang tidak setuju untuk pindah dari Polres tersebut atau mengundurkan diri jika ada yang tidak bersedia mengikuti nilai-nilai integritas tersebut.Indarto melarang segala bentuk pemberian yang bersifat transaksional antara masyarakat dan anggota atas pelayanan yang telah diberikan, walaupun pemberian tersebut dilakukan dengan ikhlas dan sebesar apapun orang tersebut memberi.Transactional artinya ada transaksi atau pertukaran antara pelayanan yang diberikan dengan materi yang diberikan. Sepanjang hal tersebut bersifat transactional, hal itu di larang. Karena Indarto sendiri begitu menekankan pada para anggotanya untuk bekerja dengan tulus ikhlas melayani masyarakat, tanpa imbalan apapun. Sehingga hasilnya belum sampai satu tahun sejak dideklarasikannya zona integritas tersebut, Polres Metro Bekasi Kota telah mendapatkan predikat WBK (Wilaya bebas korupsi) di tahun 2018.

Di satu sisi, peneliti melihatIndarto juga menerapkan gaya kepemimpinan Demokratik.Dalam membuat keputusan, khususnya untuk pelayanan publik, Indarto selalu menjelaskan ide yang ada di dalam pikirannya. Setelah itu Indarto akan memanggil seluruh kepala unit pelayanan untuk berdiskusi Bersama membahas segala kemungkinannya serta memberikan ruang yang cukup bagi anggota untuk memberikan ide-idenya sehingga terjadi komunikasi dua arahdan gagasan-gagasan tersebut dapat terlaksana sesuai dengan kondisi dan kebutuhan dilapangan. Misalnya pada saat 
menanggapi keluhan masyarakat yang tidak bisa mendapatkan antrian masuk untukmengakses pendaftaran SIM (Surat Izin Mengemudi)online, karena terbatasnya quota yang hanya tersedia 300 orang. Indarto dan anggotanya pun menggelar gebyar pelayanan pada hari minggu, khusus untuk melayani masyarakat. Gagasan ini di dapatkannya dari hasil diskusi dengan para anggota dalam mencari solusi pada keluhan masyarakat tersebut.

\section{Gaya Komunikasi Indarto sebagai Pimpinan dalam Meningkatkan Kinerja Polres Metro Bekasi Kota.}

Saat melakukan gaya kepemimpinan otokratik, Kapolres Indarto melakukan gaya komunikasi controlling style. Dalam Controlling style ini, terjadi komunikasi satu arah, dimana komunikator tidak khawatir dengan pandangan negative orang lain, tetapi justru berusaha menggunakan wewenang dan kekuasaan untuk memaksa orang lain mematuhi pandangan-pandangannya. Untuk mengubah mental dari budaya biasa menerima uang, bagi Indarto, tidak ada ruang untuk negosiasi. Pesan-pesan berasal dari komunikator satu arah ini, tidak berusaha "menjual" gagasan agar dibicarakan bersama namun lebih pada usaha menjelaskan kepada orang lain apa yang dilakukannya. The controlling style of communication ini sering dipakai untuk mempersuasi orang lain supaya bekerja dan bertindak secara efektif, dan pada umumnya dalam bentuk kritik.

Gaya Komunikasi Controlling Style memang indentik dan organisasi kepolisian yang semi militer dimana prajurit harus patuh terhadap komandannya. Controlling style merupakan gaya komunikasi yang ideal dengan harapan apa yang diinginkan komunikator dilaksanakan sepenuhnya oleh receiver.Dalam obeservasi yang dilakukan oleh peneliti terlihat sekali Controlling Style yang diterapkan dalam mendisposisi tugas, memastikan ide dan gagasan yang harus segera dilaksanakan dengan waktu yang secepat mungkin. Kecepatan dalam mengeksekusi kebijakan menjadi ciri kepemimpinan Indarto.

Di satu sisi, Indarto menerapkan sistem kerja lebih cepat lebih baik sehingga gaya komunikasinya menekankan pada tindakan atau biasa disebut Dynamic Style. Contohnya pada saat Indarto memberikan arahan mengenai pentingnya menjaga kebersihan lingkungan. Beliau secara langsung mencontohkan didepan anggotanya, memungut sampah-sampah yang ada lalu dibuang ketempat sampah.

Di awal Beliau menjabat sebagai Kapolres Metro Bekasi Kota banyak permasalahan yang mesti dibenahi, dimulai dari masalah mental, Sumber Daya Manusia, sampai dengan lingkungan tempat bekerja.Ditambah lagi, adanya beberapa ruangan yang tidak layak, misalnya ruang tunggu pembuatan SIM (Surat Izin Mengemudi), ruang rapat dan sebagainya. Hal ini menjadi perhatianIndarto karena ruangan tersebut merepresentasikan kinerja kepolisian sehingga dibutuhkan perubahan yang cepat.Gaya komunikasiDynamic Style ini cukup efektif digunakan dalam mengatasi persoalanpersoalan yang bersifat kritis, namun dengan persyaratan bahwa karyawan atau bawahan mempunyai kemampuan yang cukup untuk mengatasi masalah yang kritis tersebut. Indarto terkadang juga meminta para anggotanya untuk masuk di hari libur seperti sabtu atau minggu untuk mengadakan rapat atau mendiskusikan masalah tertentu agar target yang diinginkandapat tercapai. Dynamic Style merupakan gaya komunikasi yang sesuai dengan kepemimpinan demokratis.

Dalam menjalankan tugas apalagi sebagai Pemimpin pasti akan mendapatkan kritik, Indarto pun tak lepas dari kritik. Dari hasil wawancara dengan beberapa anggotanya dapat diketahui bahwa Indartomerupakan sosok yang bersedia untuk menerima saran, pendapat atau gagasan dari orang lain, daripada kenginan untuk memberi perintah. Indarto tidak segan-segan memberikan nomor Handphone pribadinyanya kepada anggota dan khalayak luas, agar mudah untukmenghubunginya. Jika ada kritikan/keluhan yang masuk, maka akan beliau segera tangani.Gaya komunikasi ini disebut Relinquishing Style.

\section{Hal-Hal yang Mempengaruhi Pelaksanaan Gaya Komunikasi Indarto sebagai Pimpinan dalam Meningkatkan Kinerja Para Anggota Kepolisian pada Polres Metro Bekasi Kota}

Berdasarkan hasil data wawancara denganIndarto yang penulis lakukan pada saat 
pengumpulan data di Polres Metro Bekasi Kota, maka peneliti menemukan bahwa ada beberapahal yang mempengaruhi gaya komunikasi Indarto didalam kepolisian untuk meningkatkan kinerja para anggota kepolisian di Polres Metro Bekasi Kota.

Cara memberikan perintah. Pimpinan diharapkan dapat memberikan perintah dengan jelas dan dapat dipahami oleh bawahannya. Di Polres Metro Bekasi, Indarto selalu memberikan intruksi/perintah yang begitu jelas arah dan tujuannya, dalam beberapa kasus disertai dengan Surat Perintah Tugas. Terkadang instruksi diberikan secara langsung kepada anggota utk menjaga originalitas pesan yang disampaikan. Indarto juga bukan orang yang suka menunda-nunda dan bekerja dengan ritme cepat.

Cara komunikasinya. Komunikasi dapat dilakukan dengan gaya formal dan informal. Dalam berkomunikasi di polres, Indarto adalah orang yang tegas, konsisten, dan mampu menguasai emosinya. Beliau juga luwes dan dapat menyesuaikan dengan siapa dia berbicara sehingga cara berkomunikasinya dapat diterima di berbagai kalangan. Indarto juga cenderung lebih menyukai cara-cara yang informal ketimbang cara yang birokratik.

Cara membuat keputusan. Pemimpin yang baik akan melakukan apa yang terbaik untuk organisasinya. Untuk mewujudkan visi dan misi Polres Metro Bekasi Kota dalam waktu singkat, banyak keputusan yang diambil langsung oleh Indarto dengan komunikasi topdown namun tetap memberikan ruang kepada anggota untuk memberikan masukan atau ide. Inovasi tersebut memerlukan tindak lanjut segera seperti pelayanan pembuatan Surat Keterangan Catatan Kejahatan (SKCK) dalam 24 jam, pembuatan SIM dengan jujur, pelayanan Reskrim tanpa biaya, dan lain sebagainya.

Cara mendorong semangat bawahan. Pimpinan yang baik harus bisa memotivasi bawahannya. Di Polres Metro Bekasi,Indarto memberikan penghargaan kepada anggota yg menonjol dalam hal positif, misalnya dengan memberikan piagam penghargaan melalui upacara khusus yang dihadiri anggota polres dan promosi jabatan. Selain itu, Indarto memotivasi anggotanya dengan cara mempraktekkan atau memberi contoh terlebih dahulu.
Cara memberikan bimbingan. Bimbingan sangat penting diberikan oleh pimpinan kepada bawahan. Di Polres Metro Bekasi, Indarto melakukan meeting atau pertemuan secara teratur dengan wakapolres dan kepala seksi secara regular dan rutin melakukan apel bersama seluruh anggota polres untuk memberikan pengarahan secara langsung.

Cara menegakkan kedisiplinan. Dalam menegakkan kedisiplinan, Indarto amat tegas dalam memberikan hukuman kepada anggota yg bermasalah misalnya dalam hal pungutan liar. Anggota yang bersangkutan akan ditegur, dan jika sudah melakukan kesalahan berat, maka akan dilakukan sidang disiplin. Untuk polisi yang terlibat narkoba, jika yang bersangkutan sudah ditegur, namun kembali terlibat narkoba, tidak segan-segan akan diberhentikan oleh Indarto dan pasti akan di proses hukum.

Cara mengawasi pekerjaan bawahan. Di Polres Metro Bekasi Kota, Indarto melakukan pengawasan dengan analisa evaluasi. Hal ini dilakukan hampir setiap hari, misalnya seperti pelayanan publik. Survei dilakukan oleh anggota yang dipilih dan laporan tersebut akan langsung keIndarto.. Contohnya seperti feedback mengenai kebersihan kamar mandi di ruangan pembuatan Surat Izin Mengemudi.

Cara menegur kesalahan bawahan. Di Polres Metro Bekasi, Indarto tidak emosional dalam menegur bawahan. Jika anggotanya bermasalah, maka akan dipanggil lalu dibicarakan. Dalam hal menyelesaikan konflik, Indarto selalu mengumpulkan data terlebih dahulu, kemudian meminta pendapat dan melakukan musyawarah terlebih dahulu. Setiap elemen yg berkonflik di ajak duduk bersama untuk menyelesaikan permasalahan yg ada tanpa adanya intimidasi kepada yang sedang berkonflik, serta selalu memberikan solusi alternatif.

\section{SIMPULAN}

Gaya kepemimpinanyang digunakan oleh Indarto adalahAutocratic style berupa komunikasi dalam bentuk top-down serta ketegasannya pada para anggota untuk menolak pungutan liar, korupsi serta kegiatan lain yang bersifat transactional. Kemudian Democratic Style tergambar dari keterbukaan Indarto menerima gagasan, saran serta kritik yang membangun dari para anggotanya. 
Untuk gaya komunikasi Indarto adalah Controlling styledengan sebaik mungkin menggunakan wewenang dan kekuasaannya untuk mengontrol para anggotanya dalam memerangi korupsi dan melayani masyarakat dengan baik. Dalam Dynamic styletergambar dari sikap Indarto yang tidak hanya memberi perintah namun juga memberi aksi untuk menjadi contoh positif untuk para anggotanya, dan yang terakhir adalah gaya komunikasi Reliquishing style.

Gaya komunikasi dan gaya kepemimpinan yang diimplementasikan Indarto dalam menerapkan nilai-nilai yang berintegritas pada para anggota Polres Metro Bekasi Kota dikatakan berhasil diterapkan dengan baik terbukti dari prestasi-prestasi yang diraih di Polres Metro Bekasi Kota.

Ada beberapa hal yang memepengaruhi gaya kepemimpinan Indarto yang mempengaruhi peningkatan kinerja para anggota kepolisian di Polres Metro Bekasi Kota. Yaitu memberi arahan yang jelas, penggunaan komunikasi formal dan informal yang seimbang, selalu berusaha memutuskan yang terbaik, kemampuan memotivasi anggota, rutin memberikan bimbingan, tegas menegakan kedisiplinan, serta selalu melakukan pengawasan dan evaluasi dengan rutin.

\section{DAFTAR PUSTAKA}

Djafri, N., \& Badu, S. Q. (2017). Kepemimpinan dan Perilaku Organisasi. Gorontalo: Ideas Publishing.
Fahmi, I. (2018). Pengantar Ilmu Kepemimpinan. Depok: PT Rajagrafindo Persada.

Feriyanto, A., \& Triana, E. S. (2015). Pengantar Manajemen (3 in 1) untuk mahasiswa dan umum. Kebumen: MEDIATERA.

Iskandar, D. H. (2019). Pemimpin Bermakna, Pengaruh Karakteristik Pemimpin terhadap Kinerja dan Kepuasan Kerja. Jakarta: Elex Media Komputindo.

Moleong, L. J. (2017). Metodologi Penelitian Kualitatif. Bandung: PT Remaja Rosdakarya.

Mulyana, D. (2008). Ilmu Komunikasi Suatu Pengantar. Bandung: PT Remaja Rosdakarya.

Ruliana, P. (2014). Komunikasi Organisasi: Teori dan Studi Kasus. Jakarta: RajaGrafindoPersada.

Ruliana, P. (2014). Komunikasi Organisasi: Teori dan Studi Kasus. Jakarta: PT Rajagrafindo Persada.

Serdamayanti. (2009). Sumber Daya Manusia dan produktifitas kerja. Bandung: CV Mandar Maju.

Supomo, R. (2018). Pengantar Manajemen. Bandung: Yrama Widya.

Tohardi, A. (2002). Pemahaman Praktis Manajemen Sumber Daya Manusia. Bandung: Mandar Maju.

Umar, H. (2011). Metode Penelitian Untuk Skripsi dan Tesis Bisnis. Jakarta: PT Gramedia Pustaka.

Wayne, P., \& Faules, D. F. (2006). Komunikasi Organisasi: Strategi Meningkatkan Kinerja Perusahaan. Bandung: PT Remaja Rosdakarya. 